\title{
Omega-3 polyunsaturated fatty acids and cardiac rhythm: an introduction
}

\author{
George E. Billman* \\ Department of Physiology and Cell Biology, The Ohio State University, Columbus, OH, USA \\ ${ }^{*}$ Correspondence: billman.1@osu.edu \\ Edited by: \\ Ruben Coronel, Academic Medical Center, Netherlands
}

"Sine doctrina, vita est quasi mortis imago" [Without, education, life is but the image of death] Dionysius Cato (Roman author, Fl. 4th c. AD).

"If I can stop one heart from breaking, I shall not live in vain" Emily Dickinson (American poet, 1830-1886).

The effective management of cardiac arrhythmias, either of atrial or of ventricular origin, remains a major challenge for the cardiologist. Sudden cardiac death most frequently due to ventricular tachyarrhythmias (Hinkle and Thaler, 1982; Bayes de Luna et al., 1989; Greene, 1990) remains the leading cause of death in industrially developed countries, accounting for between 300,000 and 500,000 deaths each year in the United States (Abildstrom et al., 1999; Zheng et al., 2001). In a similar manner, atrial fibrillation is the most common rhythm disorder (Kannel et al., 1998; Lakshminarayan et al., 2006), accounting for about 2.3 million cases in the United States and has been projected to increase by 2.5 -fold over the next half century (Anonymous, 1998). Indeed, the prevalence of this arrhythmia increases with each decade of life ( $0.5 \%$ patient population between the ages of 50 and 59 years climbing to almost $9 \%$ at age $80-89$ years) and contributes to approximately one-quarter of ischemic strokes in the elderly population (Kannel et al., 1998; Lakshminarayan et al., 2006). The economic impact associated with the morbidity and mortality resulting from cardiac arrhythmias is enormous [incremental cost per quality-adjusted life-year as much as US $\$ 558,000$ (Byrant et al., 2005)].

Despite the enormity of this problem, the development of safe and effective anti-arrhythmic agents remains elusive. Several antiarrhythmic drugs have actually been shown to increase, rather than to decrease, the risk for arrhythmic death in patients recovering from myocardial infarction (Echt et al., 1991; Waldo et al., 1996) while even "optimal" pharmacological therapy fails to suppress these arrhythmias completely (Buxton et al., 1999). For example, the one-year mortality is $10 \%$ or higher, with sudden death accounting for approximately one-third of the deaths, in post-myocardial infarction patients treated with $\beta$-adrenergic receptor antagonists (Buxton et al., 1999). Implantable cardioverter defibrillators (ICDs) have been shown to reduce cardiac mortality, providing a better protection from sudden death than current pharmacological therapy in certain high-risk patient populations (Buxton et al., 1999; Connelly et al., 2000). However, these devices are expensive to use and maintain (Groeneveld et al., 2006), negatively affect the patient's quality of life (Groeneveld et al., 2006), have a significant risk for inappropriate shock delivery (Poole et al., 2008), are ineffective in females patients (Henyan et al., 2006), and, perhaps most importantly, only extend life by a mean of 4.4 months (Connelly et al., 2000). Given the adverse outcomes associated with ICDs and many antiarrhythmic medications, as well as the partial protection afforded by even the best agents (e.g., $\beta$-adrenergic receptor antagonists and ICDs), it is obvious that more effective anti-arrrhythmic therapies must be developed.

The cardiovascular benefits of dietary omega-3 polyunsaturated fatty acids (n-3 PUFA) have been actively investigated for nearly 40 years. Beginning with the pioneering studies of Bang and Dyerberg (Dyerberg et al., 1978; Bang et al., 1980), epidemiological data provide strong evidence for an inverse relationship between fatty fish consumption and cardiac mortality (Kromhout et al., 1985; Daviglus et al., 1997). In contrast to these observational studies, interventional studies using n-3 PUFAs for the secondary prevention of adverse cardiovascular events in patients with heart disease have yielded conflicting results. Some studies have reported reduced sudden cardiac death or mortality (Burr et al., 1989; Marchioli et al., 2002), while other more recent studies have reported that n-3 PUFAs either had no effect on cardiac arrhythmias [either ventricular arrhythmias/sudden death (Brouwer et al., 2006; Yokoyama et al., 2007; GISSI-HF Investigators, 2008; Kromhout et al., 2010; Rauch et al., 2010) or atrial fibrillation (Kowey et al., 2010; Mozaffarian et al., 2012; Sandesara et al., 2012)] or actually increased adverse cardiac events (Burr et al., 2003; Raitt et al., 2005). Not surprisingly, meta-analysis of these studies have yielded similar conflicting results (Hooper et al., 2004; Jenkins et al., 2008; Brouwer et al., 2009; Leon et al., 2009; Zhao et al., 2009; Filion et al., 2010) with the most recent study finding that omega- 3 fatty acids were neutral, neither increasing nor decreasing the risk for arrhythmias (Rizos et al., 2012). Similar conflicting results have been obtained from animals models (McLennan et al., 1988; Billman et al., 1994; Coronel et al., 2007; Billman et al., 2012). Of particular note, dietary n-3 PUFAs increased rather than decreased susceptibility to arrhythmias induced by regional myocardial ischemia in isolated hearts (Coronel et al., 2007) and provoked ventricular fibrillation in conscious animals previously shown to be at a low risk for malignant arrhythmias (Billman et al., 2012). Despite these inconsistent findings, the American Heart Association and the American College of Cardiology continue to recommend fish oils for the secondary prevention of coronary artery disease (Kris-Etherton et al., 2003; Smith et al., 2006). Based in part upon these recommendations, consumer demand for n-3 PUFA products (both nutritional supplements 
and foods enriched with these lipids) has exploded. It has been estimated that $5-10 \%$ of the adult US population use fish oil supplements and sales are projected to exceed 7 billion dollars by the end of 2011 [www.marketresearch.com, product reports].

Despite the intensive marketing of fish oil products, a scientific consensus on the effects of n-3 PUFA on cardiac rhythm has yet to be reached. It is the purpose of this book to stimulate a discussion on the putative benefits of $n-3$ PUFAs on cardiac rhythm. The book contains both state-of-the art reviews of the literature and original research articles that address various aspects of the effects of n-3 PUFAs on cardiac rhythm. The

\section{REFERENCES}

Abildstrom, S. Z., Kobler, L., and TorpPedersen, C. (1999). Epidemiology of arrhythmic and sudden death in the chronic phase of ischemic heart disease. Card. Electrophysiol. Rev. 3, 177-179.

Anonymous. (1998). Risk factors for stroke and efficacy of antithrombotic therapy in atrial fibrillation. Analysis of pooled data from five randomized controlled trials. Arch. Intern. Med. 154, 1449-1457.

Bang, H. O., Dyerberg, J., and Sinclair, H. M. (1980). The composition of the Eskimo food in northwestern Greenland. Am. J. Clin. Nutr. 33, 2657-2661.

Bayes de Luna, A., Coumel, P., and LeClercq, J. F. (1989). Ambulatory sudden cardiac death: mechanisms of production of fatal arrhythmia on the basis of data from 157 cases. Am. Heart J. 117, 151-159.

Billman, G. E., Carnes, C. A., Adamson, P. B., Vanoli, E., and Schwartz, P. J. (2012). Dietary omega-3 fatty acids and susceptibility to ventricular fibrillation: lack of protection and a proarrhythmic effect. Circ. Arrhythm. Electrophysiol. 5, 553-560.

Billman, G. E., Hallaq, H., and Leaf, A. (1994). Prevention of ischemia-induced ventricular fibrillation by omega-3 fatty acids. Proc. Natl. Acad. Sci. U.S.A. 91, 4427-4430.

Brouwer, I. A., Riatt, M. H., Dullemeijer, C., Kraemer, D. F., Zock, P. L., Morris, C., et al. (2009). Effect of fish oil on ventricular tachyarrhythmia in three studies in patients with implantable cardioverter defibrillators. Eur. Heart J. 30, 820-826.

Brouwer, I. A., Zock, P. L., Camm, A. J., Boecker, D., Hauer, R. N., Wever, E. F. et al. (2006). Effect of fish oil on ventricular tachyarrhythmia and death in patients with implantable cardioverter defibrillators: the study on omega-3 fatty acids and ventricular arrhythmias (SOFA). JAMA 295, 2613-2619.

Burr, M. L., Ashfield-Watt, P. A., Dunstan, F. D., Fehily, A. M., Breay, P., Ashton, T., et al. (2003). Lack of benefit of dietary advice to men with angina: results of controlled trial. Eur. J. Clin. Nutr. 57, 193-200.

Burr, M. L., Gilbert, J. F., Holliday, R. M., Elwood, P. C., Fehily, A. M., Rogers, S., et al. (1989). Effects of changes in fat, fish, and fibre intakes on death and myocardial reinfarction: diet and reinfarction trial (DART). Lancet 2, 757-761.

Buxton, A. E., Lee, K. L., Fisher, J. D., Josephson, M. E., Prystowsky, E. N., and Hafley, G. (1999). A randomized study of the prevention of sudden death in patients with coronary artery disease. N. Engl. J. Med. 341, 1882-1890. Clegg, A. (2005). The clinical and cost-effectiveness of implantable cardioverter defibrillators: a systemic review. Health Technol. Assess. (Rockv) 9, 1-150.

Connelly, S. J., Hallstrom, A. P., Cappato, R., Schron, E. B., Kuck, K. H., Zipes, D. P., et al. (2000). Meta-analysis of the implantable cardioverter defibrillator secondary prevention trials. Eur. Heart J. 21, 2071-2078.

Coronel, R., Wilms-Schopman, F. J. G., Den Ruijter, H. M., Beltermean, C. N., Schumacher, C. A., Opthof, T., et al. (2007). Dietary n-3 fatty acids promote arrhythmias during acute regional myocardial ischemia in isolated pig hearts. Cardiovasc. Res. 73, 386-394.

Daviglus, M. L., Stamler, J., Orencia, A. J., Dyer, A. R., Liu, K., Greenland, P., et al. (1997). Fish consumption and the 30-year risk of fatal myocardial infarction. N. Engl. J. Med. 336, 1046-1053.
Byrant, J., Brodin, H., Loveman, E., and

book is divided into three sections. The first section addresses the effects of n-3 PUFAs on heart rate variability (chapters $2-4)$. The second section provides comprehensive reviews of the effects of n-3 PUFAs on ventricular arrhythmias/sudden death (chapters 5-8) and on atrial fibrillation (chapters 8-10). The third and final section (chapters 11-16) evaluates the cellular mechanisms by which n-3 PUFAs can influence arrhythmia formation. By understanding how n-3 PUFAs affect the cardiac rhythm, the author hopes that this brief monograph will provide an education sufficient to keep at least one heart from breaking.

Dyerberg, J., Bang, H. O., Stoffersen, E., Moncada, S., and Vane, J. R. (1978). Eicosapentaenoic acid and prevention of thrombosis and atherosclerosis? Lancet 2, 117-119.

Echt, D. S., Liebson, P. R., Mitchell, L. B., Peters, R. W., Obiasmanno, D., Barker, A. H., et al. (1991). Mortality and morbidity in patients receiving encainide, flecainide, or placebo. N. Engl. J. Med. 324, 782-788.

Filion, K. B., El Khoury, F., Bielinski, M., Schiller, I., Dendukuri, N., and Brophy, J. M. (2010). Omega3 fatty acids in high-risk cardiovascular patients: a meta-analysis of randomized controlled trials. BMC Cardiovas. Disord. 10:24. doi: 10.1186/1471-2261-10-24

GISSI-HF Investigators. (2008). Effect of $n-3$ polyunsaturated fatty acids in patients with chronic heart failure (the GISSI-HF trial): a randomized, double-blind, placebo-controlled trial. Lancet 372, 1223-1230.

Greene, H. L. (1990). Sudden arrhythmic cardiac death: mechanisms, resuscitation and classification: the Seattle perspective. Am. J. Cardiol. 65, 4B-12B.

Groeneveld, P. V., Matta, M. A., Suh, J. J., Heidenreich, P. A., and Shea, J. A. (2006). Costs and quality-of-life effects of implantable cardioverterdefibrillators. Am. J. Cardiol. 98, 1409-1415.

Henyan, N. N., White, C. M., Gillespie, E. L., Smith, K., Coleman, C. L., and Kluger, J. (2006). The impact of gender on survival amongst patients with implantable cardioverter defibrillators for primary prevention against sudden cardiac death. J. Intern. Med. 260, 467-473.

Hinkle, L. E. J., and Thaler, H. T. (1982). Clinical classification of cardiac deaths. Circulation 65, 457-464.

Hooper, L., Thompson, R. L., Harrison, R. A., Summerbell, C. D., Moore,
H., Worthington, H. V., et al. (2004). Omega-3 fatty acids for prevention and treatment of cardiovascular disease. Cochrane Database Syst. Rev. 4, CD003177.

Jenkins, D. J., Josse, A. R., Beyene, J., Dorian, P., Burr, M. L., LaBelle, R., et al. (2008). Fish-oil supplementation in patients with implantable cardioverter defibrillators: a metaanalysis. Can. Med. Assoc. J. 178, 157-164.

Kannel, W. B., Wolf, P. A., and Levy, D. (1998). Prevalence, incidence, prognosis, and predisposing conditions for atrial fibrillation: populationbased estimates. Am. J. Cardiol. 82, 2N-9N.

Kowey, P. R., Reiffel, J. A., Ellenbogen, K. A., Naccarelli, G. V., and Pratt, C. M. (2010). Efficacy and safety of prescription omega-3 fatty acids for the prevention of recurrent symptomatic atrial fibrillation: a randomized controlled trial. JAMA 304, E1-E10.

Kris-Etherton, P. M., Harris, W. S., and Appel, L. J., for the AHA Nutrition Committee. (2003). Omega-3 fatty acids and cardiovascular disease: new recommendations from the American Heart Association. Arterioscler. Thromb. Vasc. Biol. 23, 151-152.

Kromhout, D., Bosschieter, E. B., and de Lezenne, C. C. (1985). The inverse relation between fish consumption and 20-year mortality from coronary heart disease. $N$. Engl. J. Med. 312, 1205-1209.

Kromhout, D., Giltay, E. J., and Geleijnse, J. M., for the Alpha Omega Trial Group. (2010). n-3 fatty acids and cardiaovascular events after myocardial infarction. N. Engl. J. Med. 363, 2015-2026.

Lakshminarayan, K., Solid, C. A., Collins, A. J., Anderson, D. C., and Herzog, C. A. (2006). Atrial fibrillation and stroke in the general Medicare population: a 10-year perspective (1992 to 2002). Stroke 37, 1969-1974. 
Leon, H., Shibata, M. C., Sivakumaran, S., Dorgan, M., Chatterley, T., and Tsuyuki, R. T. (2009). Effect of fish oil on arrhythmias and mortality: systematic review. Br. Med. J. 338, a2931.

Marchioli, R., Barzi, F., Bomba, E., Chieffo, C., Di Gregorio, D., Di Mascio, R., et al. (2002). Early protection against sudden death by $n-3$ polyunsaturated fatty acids after myocardial infarction: timecourse analysis of the results of the Gruppo Italiano per lo Studio della Sopravvivenza nell'Infarto Miocardico (GISSI)-Prevenzione. Circulation 105, 1897-1903.

McLennan, P. L., Abeywardena, M. Y., and Charnock, J. S. (1988). Dietary fish oil prevents ventricular fibrillation following coronary artery occlusion and reperfusion. Am. Heart J. 116, 709-717.

Mozaffarian, D., Marcholi, R., Macchia, A., Silletta, M. G., Ferrazzi, P., Gardner, T. J., et al. (2012). Fish oil and postoperative atrial fibrillation. The omega-3 fatty acid for prevention of post-operative atrial fibrillation (OPERA) randomized trial. JAMA. doi: 10.1001/jama.2012.28733. [Epub ahead of print].
Poole, J. E., Johnson, G. W., Hellkamp, A. S., Anderson, J., Callans, D. J., Raitt, M. H., et al. (2008). Prognostic importance of defibrillator shocks in patients with heart failure. N. Engl. J. Med. 359, 1009-1017.

Raitt, M. H., Connor, W. E., Morris, C., Kron, J., Halpren, B., Chugh, S. S., et al. (2005). Fish oil supplementation and risk of ventricular tachycardia and ventricular fibrillation in patients with implantable defibrillators: a randomized controlled trial. JAMA 293, 2884-2891.

Rauch, B., Schiele, R., Schneider, S., Diller, F., Victor, N., Gohlke, H., et al. (2010). OMEGA, a randomized, placebo-controlled trial to test the effect of highly purified omega3 fatty acids on top of modern guideline-adjusted therapy after myocardial infarction. Circulation 122, 2152-2159.

Rizos, E. C., Ntzani, E., Bika, E., Kostapnos, M. S., and Elisaf, M. S. (2012). Association between omega-3 fatty acids supplementation and risk of major cardiovascular disease events: a systematic review and meta-analysis. JAMA 308, 1024-1033.
Sandesara, C. M., Chung, M. K., Van Wagoner, D. R., Barringer, T. A. Allen, K., Ismail, H. M., et al. (2012) A randomized placebo-controlled trial of omega- 3 fatty acids for inhibition of supraventricular arrhythmias after cardiac surgery the FISH trial. J. Am. Heart Assoc. 1, e000547.

Smith, S. C., Allen, J., Blair, S. N., Bonow, R. O., Brass, L. M., Fonarow, G. C., et al. (2006). AHA/ACC guidelines for the secondary prevention for patients with coronary and other atherosclerotic vascular disease: 2006 update. Circulation 113, 2363-2372.

Waldo, A. L., Camm, A. J., de Ruyter, H., Friedman, P. L., MacNeil, D. J., Pauls, J. F., et al. (1996). Effect of d-sotalol on mortality in patients with left ventricular dysfunction after recent and remote myocardial infarction. Lancet 348 , 7-12.

Yokoyama, M., Origasa, H., Matsuzaki, M., Matsuzawa, Y., Saito, Y., Ishikawa, Y., et al. (2007). Effects of eicosapentaenoic acid on major coronary events in hypercholesterolemic (JELIS): a randomized open-label, blinded endpoint analysis. Lancet 369 , 1090-1098.
Zhao, Y. T., Chen, Q., Sun, Y. X., Li, X. B., Zhang, P., Xu, Y., et al. (2009). Prevention of sudden cardiac death with omega-3 fatty acids in patients with coronary heart disease: meta-analysis of randomized controlled trials. Ann. Med. 41, 301-310.

Zheng, Z.-J., Croft, J. B., Giles, W. H., and Mensah, G. A. (2001). Sudden cardiac death in the United States, 1989 to 1998. Circulation 104, 2158-2163.

Received: 13 November 2012; accepted: 19 November 2012; published online: 06 December 2012.

Citation: Billman GE (2012) Omega-3 polyunsaturated fatty acids and cardiac rhythm: an introduction. Front. Physio. 3:457. doi: 10.3389/fphys.2012.00457 This article was submitted to Frontiers in Cardiac Electrophysiology, a specialty of Frontiers in Physiology.

Copyright (c) 2012 Billman. This is an open-access article distributed under the terms of the Creative Commons Attribution License, which permits use, distribution and reproduction in other forums, provided the original authors and source are credited and subject to any copyright notices concerning any thirdparty graphics etc. 